\title{
The Knowledge and Value Basis of Private Forest Management in Sweden: Actual Knowledge, Confidence, and Value Priorities
}

\author{
Louise Eriksson $\mathbb{D}^{1} \cdot$ Clas Fries $^{2}$ \\ Received: 10 March 2020 / Accepted: 29 June 2020 / Published online: 21 July 2020 \\ (c) The Author(s) 2020
}

\begin{abstract}
With growing demands on forests, there is a need to understand the drivers of managing the forest for diverse objectives, such as production, recreation, and climate adaptation. The aim of this study was to examine the knowledge and value basis of forest management behaviors, including different management strategies and management inactivity, among private forest owners in Sweden. Different dimensions of knowledge (declarative and procedural knowledge, assessed in terms of objective and subjective knowledge measures) and value priorities (basic values and forest values), as well as the role of forest owner identity, were examined. The study was conducted by means of a postal questionnaire to a random sample of private forest owners in Sweden $(n=3000$, response rate 43\%). The distinctions between actual knowledge (objective knowledge), confidence (subjective knowledge), and value priorities, in addition to the hierarchical structure of how these factors are linked to management behaviors, proved to be valuable. Results revealed that different knowledge dimensions and value priorities were jointly important for forest management behaviors. In addition, the role of forest owner identity for management behaviors was confirmed. Insights from the study may be used to develop policy and outreach to private forest owners and thereby facilitate different forest functions in private forestry.
\end{abstract}

Keywords Forest management behavior $\cdot$ Production $\cdot$ Biodiversity $\cdot$ Recreation $\cdot$ Climate adaptation $\cdot$ Climate mitigation

\section{Introduction}

In 2015, the United Nations agreed on 17 Sustainable Development Goals to be achieved by 2030 and how forests are managed have implications for the attainment of several of these goals, for example clean water and sanitation (goal 6), affordable and clean energy (goal 7), climate action (goal 13), and life on land, including sustainable forest management (goal 15) (United Nations 2015). In this context, there are growing societal demands to use and manage the forest for production (e.g., timber), biodiversity

Supplementary information The online version of this article (https:// doi.org/10.1007/s00267-020-01328-y) contains supplementary material, which is available to authorized users.

Louise Eriksson

louise.eriksson@umu.se

1 Department of Geography, Umeå University, SE-901 87 Umeå, Sweden

2 Forest Unit, Swedish Forest Agency, Box 284, SE-901 06 Umeå, Sweden conservation, carbon sequestration (through carbon storage or carbon substitution), and people's health and wellbeing (Bellassen and Luyssaert 2014; Jactel et al. 2017; Lagergren and Jönsson 2017; Trivino et al. 2017). In addition, there is a need to reduce forests' vulnerability to disturbances through, for example, climate change adaptation (Lindner et al. 2014). To facilitate diverse forest functions or multiobjective forestry, policy-makers, and practitioners need an understanding of the underlying basis for management decisions. In countries with a significant share of privately owned forests (e.g., the US, Germany, Sweden, and Finland), decisions concerning how to manage the forest are in the hands of family forest owners, also called individual private forest owners.

Previous research on forest owners has examined determinants of management activities, such as harvesting, the management of insects and invasive species, climate change adaptation, wildlife practices, and participation in different programs (e.g., concerning conservation). Results have revealed that structural characteristics relating to the owner and the forest (e.g., gender, age, forest type, size of forest, and distance from roads) are associated with management activities (e.g., Joshi and Arano 2009; Lidestav and Berg 
Lejon 2013; Silver et al. 2015; Coté et al. 2016; Aguilar et al. 2017; Thompson et al. 2017; Floress et al. 2019). In addition, social and psychological factors, such as social networks, personal experience, forest values and management objectives, subjective knowledge or awareness, and beliefs and attitudes have been found to be important for engagement in particular activities (Karppinen 2005; Joshi and Arano 2009; Blennow et al. 2012; Hendee and Flint 2013; Thompson and Hansen 2013; Põllumäe et al. 2014; Sagor and Becker 2014; Drescher et al. 2017; Kelly et al. 2017; Eriksson 2017, 2018b; Vulturius et al. 2018; Fischer 2019; Thorn et al. 2019). Even though knowledge has been found to play a role in forest management activities (e.g., Floress et al. 2019), and lack of knowledge is considered a significant barrier to achieving, in particular, new management aims such as climate change adaptation (Bissonnette et al. 2017; Sousa-Silva et al. 2018), the complexities associated with conceptualizing and measuring knowledge have largely been ignored. In addition, scarce attention has been given to the extent to which management decisions are formed based on knowledge as compared with other drivers. This study examined the knowledge and value basis of forest management in private forestry in Sweden. By using theoretically based concepts and carefully derived measures, and by comparing the drivers of different management strategies and management inactivity, the study contributes to an improved understanding of the underlying basis of forest management behaviors.

\section{Theoretical Background}

The institutional and social context, with roots in history, has obvious implications for how private forest management is conducted (Andersson and Keskitalo 2018; Nichiforel et al. 2018). However, the heterogeneity among forest owners in the same setting suggests that the owners' choice of management strategy cannot be sufficiently explained by contextual factors alone and a consideration of the psychological basis of management behaviors enables a more comprehensive understanding (Ingemarson et al. 2006; Vulturius et al. 2018).

\section{Knowledge and forest management}

There are diverse forms of knowledge, including sciencebased, but also systems of indigenous or local knowledge (The Intergovernmental Science-Policy Platform on Biodiversity and Ecosystem Services (IPBES) 2013; Hurlbert et al. 2019). In research on environmental behaviors, the individuals' knowledge is considered important for the formation of perceptions and behaviors (Kaiser and Fuhrer 2003; Frick et al. 2004). However, there is a need to distinguish between knowledge types and different measures of knowledge (Vicente-Molina et al. 2013; Thorn and Bogner 2018). Declarative or system knowledge-e.g., how environmental systems or certain aspects of a system operate-can be differentiated from procedural or actionrelated knowledge, referring to knowledge of the specific actions that can be implemented to achieve a certain goal (Kaiser and Fuhrer 2003; Frick et al. 2004; Díaz-Siefer et al. 2015; Thorn and Bogner 2018). It is furthermore important to distinguish between objective (or actual) and subjective (or self-rated) assessments of knowledge (Shi et al. 2016). Whereas measures of objective knowledge employ knowledge questions (true/false or multiple choice), subjective knowledge represents a self-assessment of, for example, familiarity, awareness, or level of knowledge (Steele et al. 2006; Marzano et al. 2017), thus resembling the concept of self-efficacy, i.e., the belief in one's own ability to act (Bandura 1977) (Geiger et al. 2019a).

In relation to forest owners, mainly measures of subjective knowledge tapping different knowledge dimensions have been employed, generally confirming an effect on management activities (Eggers et al. 2014; Fischer and Charnley 2012; Steele et al. 2006; Germain et al. 2014). For example, Eggers et al. (2014) showed that higher subjective knowledge about management was related to using a production-focused management approach. In addition, research on environmental behaviors shows that while subjective knowledge has been found to be more closely related to behavior, significant associations between objective knowledge and behavior have also been confirmed (Vicente-Molina et al. 2013; Díaz-Siefer et al. 2015; but see Ünal et al. 2017). Nevertheless, declarative objective knowledge have often been found to be indirectly related to behavior via other types of knowledge (e.g., procedural and effectiveness knowledge), attitudes, or intentions (Frick et al. 2004; Roczen et al. 2014; Kaiser and Fuhrer 2003; Nguyen et al. 2019).

\section{Value priorities and forest management}

Behaviors are also influenced by value priorities (Rohan 2000). The cognitive hierarchy model stipulates that cognitions can be arranged in a hierarchy from more general to specific cognitions (Fulton et al. 1996). On a general level, basic values transcend situations and act as general guiding principles for beliefs, attitudes, and behaviors. Schwartz's (1992, 1994) value theory differentiates between two independent value dimensions; that is, values emphasizing self-interest (i.e., self-enhancement) versus others' interests (i.e., self-transcendence, including altruistic and biospheric values) and values conveying an openness to new ideas (i.e., openness to change) versus maintaining the status quo (i.e., conservation). In addition, reasons why humans value forests have been labeled forest values, general forest 
beliefs or value orientations, highlighting for example production, recreation, ecological, aesthetic, and cultural forest values (e.g., McFarlane and Boxall 2003; Eriksson et al. 2013). In line with the cognitive hierarchy, associations between basic values and forest values have been confirmed, with self-transcendent values being positively correlated with ecological and recreation forest values, but negatively correlated with production values (Eriksson et al. 2013).

Evidence supports the importance of value priorities for management decisions. For example, forest owners emphasizing the interests of others and placing less emphasis on more traditional values tend to be more likely to participate in conservation programs (Drescher et al. 2017), and stronger production forest values, but also stronger ecological forest values, have been found to be associated with climate change adaptation (Eriksson 2018b). In addition, forest values have been incorporated into owner objectives, and the implementation of silvicultural measures, including thinning and harvesting, has been found to be higher among owners emphasizing timber and forest income than among other owners (Põllumäe et al. 2014; Joshi and Arano 2009). In contrast, an emphasis on amenity objectives has been found to be associated with lower levels of harvesting (Hendee and Flint 2013).

\section{Forest owner identity and forest management}

Self-identity refers to meanings attached to the self; and since people are motivated to act in accordance with how they view themselves, identity perceptions may influence behaviors (Burke and Stets 2009; Walton and Emmet Jones 2018). People generally have multiple identities that are more or less central to the overall self and vary in relevance across contexts. Self-identities may, for example, be based on group membership, such as forest ownership, with different meanings associated with the identity. In addition, identity perceptions may contain a social dimension reflecting the identification with a certain social group in conjunction with a differentiation from other groups. Since forest owners are heterogeneous, the meanings attached to a forest owner identity (FOI) may be diverse and cover sentiments such as being a multi-objective owner, a recreationist, economic centered, a farmer, an indifferent owner, a conservationist, multifunctional, or a self-employed owner, for example (Lawrence and Dandy 2014; Ní Dhubháin et al. 2007; Ficko et al. 2017; Feliciano et al. 2017). Studies suggest that perceptions of forest ownership may be incorporated as part of the owner's identity (e.g., Bliss and Martin 1988; Lähdesmäki and Matilainen 2014; Kreye et al. 2018; Bergstèn et al. 2018), although scarce attention has been given to how different owner identities are associated with diverse management behaviors.

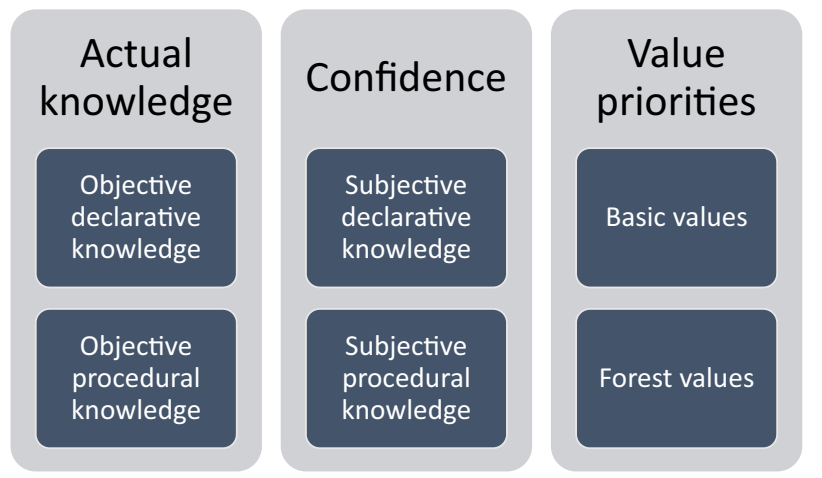

Forest owner identity

Forest management behavior

Fig. 1 Conceptual framework of the hierarchically ordered knowledge and value basis of forest management behaviors

\section{Conceptual framework}

Based on the literature review, a conceptual framework depicting psychological drivers of forest management behaviors was developed, including knowledge and value priorities (see Fig. 1). Whereas these drivers have evolved concurrently over time and are thus interlinked, the conceptual distinctions will facilitate theoretical development and be useful for practice. A multidimensional concept of knowledge was employed (Shi et al. 2016), distinguishing between actual knowledge (objective knowledge) and confidence (subjective knowledge). The different concepts of knowledge and value priorities were considered to be hierarchically related to management behavior, with more general factors (i.e., declarative knowledge and basic values) being more distal predictors than behavioral specific factors (i.e., procedural knowledge and forest values) (Dietz et al. 1998; Gatersleben et al. 2017; Geiger et al. 2019b). Since forest owner identities reflect internalized perceptions (cf. Walton and Emmet Jones 2018), they should furthermore be more closely associated with management than knowledge and value priorities.

\section{The Present Study}

Although knowledge and value priorities are both confirmed predictors of behaviors, their importance for forest management behaviors has not been compared and discussed. The aim of this study was to examine how actual knowledge, confidence and value priorities, as well as FOI, were associated with forest management behaviors among private forest owners in Sweden. Whereas previous studies of forest management activities have generally not 
compared the determinants of different management strategies (but see Joshi and Arano 2009), the present study explored predictors of different types of management behaviors, including management for production, biodiversity, recreation, climate adaptation, and climate mitigation. With thought to the changes in forest ownership in many Western countries, e.g., more absentee owners and fewer owners relying on their forest for income (Hogl et al. 2005; Ficko et al. 2017; Weiss et al. 2019), the determinants of management inactivity were also explored. Overall, the study examined: (1) forest management behaviors (i.e., frequency of engaging in different management strategies, including management inactivity, and relations between strategies); (2) structural correlates of forest management behaviors, including gender, age, education, size of forest holding, residency, place, and region; and (3) the importance of actual knowledge, confidence, value priorities, and FOI for forest management behaviors. Based on the conceptual framework, actual knowledge, confidence, and value priorities should all be associated with management behaviors. In addition, the psychological drivers were expected to be hierarchically ordered in relation to management behaviors, with more general concepts being more distant predictors than specific concepts. Whereas confidence is a key determinant of a broad range of behaviors (cf. Ajzen 2002), and both confidence and value priorities have been found to be relevant for forest management (Eggers et al. 2014; Eriksson 2018b), actual knowledge has been given less attention. Thus, no hypotheses regarding the relative importance of the different knowledge dimensions and value priorities for management behaviors were generated.

\section{Materials and Methods}

\section{Study Area}

Close to $70 \%$ of the land area in Sweden is covered by forests, and coniferous trees, primarily Norway Spruce and Scots Pine, are the main tree species (Swedish University of Agricultural Science [SLU] 2018). The majority of the forest in Sweden is privately owned, with $~ 50 \%$ owned by around 330,000 individual private forest owners (Swedish Forest Agency [SFA] 2014). The environmental and production objectives in the Swedish forest policy are considered equally important, and forest is to be used for a variety of different purposes, including adapting it to climate change and using it for climate mitigation (Swedish Gov. Bill 2007/08:108). Nevertheless, the forest is a significant economic asset, with its large production of roundwood and sawnwood (Eurostat 2017), and studies have shown that the forestry culture in Sweden is dominated by production objectives (e.g., Andersson and Keskitalo 2018). Whereas management was regulated in detail before 1993, with several mandatory silvicultural measures preventing management inactivity, only a few obligatory measures remain (e.g., regeneration after clear felling) and the forest owners enjoy a great degree of freedom (Bush 2010). In this context, information and advice are considered important tools to achieve the goals of the forest policy (Johansson and Keskitalo 2014).

\section{Respondents}

A postal questionnaire to a randomly selected sample of individual private forest owners in Sweden, aged 20-80 years and owning more than 5 ha of forest land, was conducted by a survey company (Attityd i Karlstad AB) in the autumn of 2018. After two reminders, the response rate was $43 \%(n=1251)$. The sample contained $19 \%$ women and the mean age was 62 years $(\mathrm{SD}=11)$. Almost a third of the respondents had a university degree $(31 \%)$ and about half, $52 \%$, were resident owners. The mean area of productive forest was 92 ha $(S D=260)$. Whereas differences between the population and sample were minor, the sample did contain fewer women, young owners, and owners with small forest properties. Hence, calibrated weights were used in the analyses to control for these deviations.

\section{Questionnaire}

Information on gender, age, size of forest holding, and region where the forest property was located were taken from the owner register. Background questions included, for example, education, whether the owner was resident or nonresident, and whether the owner lived in an urban or a rural area. In addition, actual knowledge, confidence, value priorities, FOI, and forest management behaviors were assessed in the questionnaire. Means, standard deviations, and internal reliability (alpha) for the psychological predictors are displayed in the Appendix (Table A1).

Actual knowledge was examined using objective knowledge scales reflecting declarative knowledge about the forest in Sweden more generally and procedural knowledge in relation to each of the five management types. The construction of the knowledge scales was guided by research on how to measure knowledge (considering, e.g., difficulty levels) (Frick et al. 2004; Díaz-Siefer et al. 2015) and forest facts, also involving a forest management expert at the SFA. The battery of questions at Skogskunskap.se (a web portal with facts about forests) was used as inspiration for some of the questions. The initial set of questions was pretested by a group of forest owners, answering the questions and evaluating and commenting on their clarity, etc., as well as rating them on a three-point scale: easy, 
medium, or difficult. After revisions, six questions reflecting general knowledge (two for each of the three difficulty levels) and 20 questions reflecting the five types of procedural knowledge (including one easy, two medium, and one difficult question on each of the scales) were included in the questionnaire. A multi-response format was used, with three to six correct response options for each question. The questions are available from the authors upon request. Answers were coded in three categories $-0=$ wrong, $0.5=$ partly correct, and $1=$ correct-resulting in a scale from 0 to 6 on general knowledge and a scale from 0 to 4 on procedural knowledge.

Confidence was examined using subjective knowledge measures about the forest in general and about each of the five management types. Based on previous research on subjective knowledge (McFarlane and Watson 2008), the owners were asked about how much knowledge they considered themselves to have about the following: general knowledge about forests in Sweden (e.g., tree species, damage, and ownership conditions); forest management aiming for good forest growth; forest management used to preserve biodiversity; forest management contributing to an attractive recreation forest; forest management aiming to use the forest for climate mitigation; and forest management adjusted to a warmer climate. Answers were provided on a four-point scale $(1=$ no knowledge at all, $2=$ a little knowledge, $3=$ certain knowledge, $4=$ extensive knowledge).

Value priorities in terms of basic values and three types of forest values were assessed. Based on Schwartz's (1992, 1994) value theory and the distinction between altruistic, biospheric, and egoistic value orientations (de Groot and Steg 2008), the following basic values were assessed: openness (five items), conservation (five items), self-enhancement (SE) (five items), and self-transcendence (ST) (including altruism (Alt) (four items) and biospheric (Bio) (four items)). The respondents were asked to indicate how important each value was as a guiding principle in their life, with responses provided on a nine-point scale $(-1=$ opposed to my values, $0=$ not important, $3=$ important, $6=$ very important, and $7=$ extremely important). Before combining the values into higher-order value types, scale use differences were controlled for by mean centering the higher-order value score as suggested by Schwartz. A confirmatory factor analyses with varimax rotation of the higher-order value indexes (62\% explained variance) confirmed a two-factor model. Because of the relevance of the SE-ST scale for environmental behaviors (Stern 2000), only the factor scores based on this dimension were included in the final analyses. To assess forest values, the owners were asked how important they believed production (e.g., timber or biofuel), the possibilities for recreation for humans, and biodiversity (diversity in plant and animal life) were in their own forest and in the Swedish forest in general, respectively (cf. Eriksson 2018a). Answers were provided on a seven-point scale $(1=$ not at all important, $7=$ very important) and index variables were created by calculating the means of the two items for each forest value scale.

Forest owner identity, in terms of the meanings attached to the owners' self- and social forest owner identities, as well as centrality, was assessed. The owners were asked about the extent to which they agreed with statements reflecting how they use, manage, and perceive their forest (self-identity), and the extent to which they identified with different types of other forest owners (social identity). Four owner identities were measured, reflecting primary ways in which the forest may be perceived and used, relationships with other owners, and the forest itself; i.e., production and private asset (production/private), consumption of noneconomic values and public resource (consumption/public), connections with other owners (social), and detachment from forest (distant). Answers were provided on a five-point scale $(1=$ totally disagree, $5=$ totally agree $)$. Since the identity scales had not been previously tested, alpha values guided their revisions. Removing any item from the Social FOI or the Distant FOI did not increase the internal reliability. However, when one item was excluded from the two remaining scales, the alpha values increased slightly. A measure of centrality of the forest to the owners was developed measuring positive emotions, the possession-self link, and importance (six items) (cf. Ferraro et al. 2011). Answers were provided on a five-point response scale $(1=$ totally disagree, $5=$ totally agree) and the mean of the items was used to create a centrality index. The distant and the consumption/public FOI scales displayed a somewhat low reliability ( $\alpha=0.65$ and $\alpha=0.62$, respectively) and this should be considered when interpreting results. The FOI items are provided in the Appendix (see Table A2).

Forest management behavior included the frequency of implementing different management strategies and management inactivity. Production, biodiversity, recreation, and climate adaptation management behaviors were examined by means of four items each, and climate mitigation (in terms of substitution) was assessed using three items. The owners were asked about how often they had used different strategies in their forest and the answers were provided on a five-point scale $(1=$ never, $2=$ seldom, $3=$ sometimes, $4=$ often, $5=$ always) (see the Appendix (Table A3) for the list of included management strategies). Subsequently, the sum of the included strategies was calculated, resulting in a scale from 1 to 20 for all management strategies except climate mitigation (substitution), which had a scale from 1 to 15 . To assess management inactivity, the owners were asked to indicate whether they had refrained from implementing any forest management measure during the last 10 years. 
Table 1 Descriptives and bivariate correlations for forest management behaviors

\begin{tabular}{|c|c|c|c|c|c|c|}
\hline & Production $^{\mathrm{a}}$ & Biodiversity $^{\mathrm{a}}$ & Recreation $^{\mathrm{a}}$ & Adaptation $^{\mathrm{a}}$ & $\begin{array}{l}\text { Mitigation } \\
\text { (substitution) }\end{array}$ & $\begin{array}{l}\text { Management } \\
\text { inactivity }\end{array}$ \\
\hline Production & $\begin{array}{l}M=10.27 \\
\mathrm{SD}=3.44\end{array}$ & & & & & \\
\hline Biodiversity & $0.27 * * *$ & $\begin{array}{l}M=11.36 \\
\mathrm{SD}=2.79\end{array}$ & & & & \\
\hline Recreation & $0.26 * * *$ & $0.48 * * *$ & $\begin{array}{l}M=10.74 \\
\mathrm{SD}=3.65\end{array}$ & & & \\
\hline Adaptation & $0.43 * * *$ & $0.53 * * *$ & $0.54 * * *$ & $\begin{array}{l}M=10.98 \\
\mathrm{SD}=3.74\end{array}$ & & \\
\hline Mitigation & $0.41 * * *$ & $0.21 * * *$ & $0.31 * * *$ & $0.39 * * *$ & $\begin{aligned} M & =4.79 \\
\mathrm{SD} & =1.85\end{aligned}$ & \\
\hline $\begin{array}{l}\text { Management } \\
\text { inactivity }\end{array}$ & $-0.44 * * *$ & $-0.24 * * *$ & $-0.17 * * *$ & $-0.33 * * *$ & $-0.21 * * *$ & $25.1 \%$ \\
\hline
\end{tabular}

\section{Analyses}

For data analyses, SPSS Statistics 24 was utilized (IBM corp. 2016). First, forest management behaviors were described via means and standard deviations for the five management strategies and the percentage of owners displaying management inactivity. In addition, correlations between management behaviors were analyzed using Pearson's $r$ for the management strategies and point-biserial correlation for management inactivity.

Second, linear regression analyses were used to examine relations between structural characteristics and the different management strategies, and a binary logistic regression analysis was employed to analyze relations between structural characteristics and management inactivity. Gender (dummy: $1=$ female), age, education (dummy: $1=$ University degree), size of forest holding, residency (dummy: $1=$ resident owner), place (dummy: $1=$ urban), and region (dummy: $1=$ South region corresponding to the organizational setup of the SFA) were included as independent variables. Dependent variables were management strategies (i.e., frequency of engaging in production, biodiversity, recreation, adaptation, and mitigation (substitution) management) and management inactivity, respectively.

Third, the importance of knowledge, value priorities, and FOI for forest management behaviors was examined by means of hierarchical regression analyses in three steps. Linear regression analyses were used to examine predictors of the different forest management strategies, and a binary logistic regression analysis was employed to analyze predictors of management inactivity. In the first step, general variables (i.e., declarative objective knowledge, declarative subjective knowledge, and basic values) were included in the analyses of both forest management strategies and management inactivity. In the second step, the more specific knowledge and value variables (i.e., procedural objective knowledge, procedural subjective knowledge, and forest values) were added. In the analyses of management strategies, one procedural knowledge measure and one forest value scale were examined in relation to each strategy (e.g., procedural objective knowledge of production in relation to production management), except in relation to adaptation and mitigation (substitution) management. Since these strategies may be motivated by diverse forest values (Eriksson 2018a), both production and biodiversity forest values were included. In the analysis of management inactivity, all measures of actual knowledge, confidence, and forest values were used as predictors. Finally, in an explorative manner, the Social FOI, the Distant FOI, and centrality were included in relation to all management strategies. In addition, Production/private FOI was included in relation to production management, consumption/public FOI in relation to biodiversity and recreation management, and both these FOIs were examined in relation to adaptation and mitigation (substitution) management. The full set of FOIs was included as predictors in the third step of the analysis of management inactivity.

\section{Results}

\section{Forest Management Behaviors}

Descriptives and the associations between different measures of forest management behaviors are displayed in Table 1. Whereas the owners did not frequently engage in mitigation (substitution) management, the means for the remaining strategies were close to the midpoint of the scale. About one fourth of the respondents had not engaged in any forest management activities the last 10 years. The positive correlations between the strategies suggest that owners implementing one type of strategy were more likely to implement the other strategies. A strong positive correlation was found between climate adaptation management and 
both biodiversity and recreation management. In contrast, biodiversity management and climate mitigation (substitution) management displayed the weakest correlation. Management inactivity displayed the strongest negative correlation with production management, indicating that inactive owners were the least likely to implement production-oriented activities.

\section{Structural Characteristics and Forest Management Behaviors}

Results from the regression analyses of how structural characteristics are related to forest management behaviors are displayed in Table 2. There was no evidence of collinearity, since no VIF value exceeded 1.303 in any of the models. Results revealed that male owners, owners with larger forest holdings, and owners in the south region had implemented all the management strategies to a greater extent and were less likely to be inactive compared to their counterparts. Older owners, compared with younger owners, had more frequently engaged in production, biodiversity, and mitigation (substitution) management. In addition, owners with a university degree had more often implemented biodiversity management, resident owners had more often implemented mitigation (substitution) management, and rural owners had more often employed recreation and adaptation management, compared to their counterparts. The structural factors and forest characteristics explained between 5 and $8 \%$ of the variance in the different management strategies.

\section{Psychological Drivers of Forest Management Behaviors}

The hierarchical analyses of psychological drivers of management behaviors are displayed in Table 3 for the forest management strategies, and in Table 4 for management inactivity. The models of forest management strategies displayed no evidence of collinearity (no VIF value exceeded 2.342). Among the general variables in the first step, declarative subjective knowledge and basic values were significant predictors of all management strategies except recreation management, where only declarative subjective knowledge was significant. In the second step the beta weights for the general variables decreased, although declarative subjective knowledge was still significant in relation to all management strategies except production management, and basic values were significant in relation to production and mitigation (substitution) management. Whereas procedural objective knowledge was a significant predictor in relation to production, biodiversity, and adaptation management, procedural subjective knowledge, and forest values were significant in relation to all management strategies. In the third step, the beta weights of the more general variables decreased even further; however, procedural subjective knowledge was still significant in relation to all management strategies. In addition, basic values and production values significantly determined production management, and production values were a significant predictor of mitigation (substitution) management. Whereas the Production/private FOI predicted production and mitigation (substitution) management, the consumption/public FOI predicted biodiversity, recreation, and adaptation management. In addition, the social FOI was positively linked to all management strategies and the Distant FOI was negatively associated with production, recreation, and adaptation management. Centrality of the identity was positively correlated with recreation and adaptation management. Two variables displayed reversed signs in the final step of the analyses (declarative subjective knowledge in relation to production management and declarative objective knowledge in relation to adaptation management), indicating that they act as suppressor variables in these models. In each step of the analyses, the explained variance increased significantly. Whereas the predictors explained a relatively low level of variance in mitigation (substitution) management, they were more important for production and adaptation management.

The analyses of forest management inactivity showed that, in the first step, declarative objective and subjective knowledge were significant predictors but basic values were not. In subsequent steps, however, none of these variables remained significant. In the second step, procedural objective knowledge of all forest management strategies except mitigation was significant, as was procedural subjective knowledge of production and adaptation. In addition, production forest values were a significant predictor of management inactivity. Hence, whereas several different types of objective knowledge were significant predictors of management inactivity, fewer measures of subjective knowledge, and forest values were. The same measures of procedural objective and subjective knowledge, in addition to production forest values, remained significant in the third step. In addition, a weaker Production/private FOI and a weaker Social FOI, but a stronger Distant FOI, were associated with management inactivity. Whereas less knowledge and weaker production forest values were generally associated with a higher probability of not managing the forest, a higher level of procedural objective knowledge of adaptation management was associated with management inactivity. The full model was significantly better in explaining management inactivity compared to the models with variables reflecting knowledge and value priorities. 


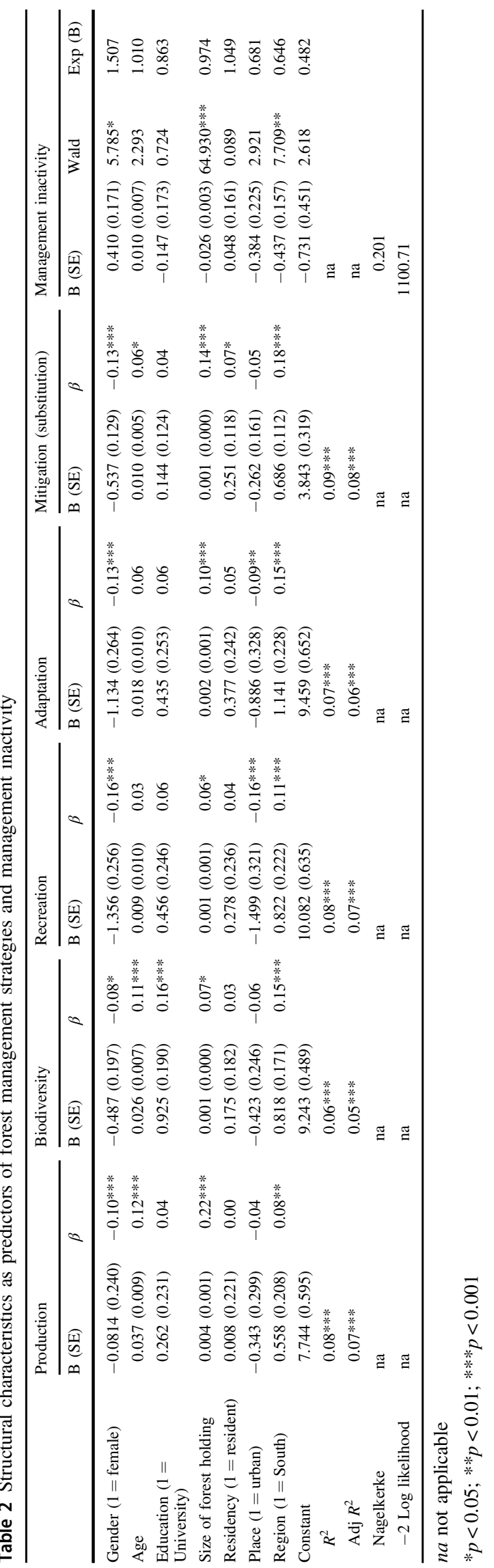

\section{Discussion}

This study confirms that different knowledge dimensions and value priorities are jointly important for forest management behaviors, adding to the ongoing discussion of how knowledge versus values influence behaviors (cf. Shi et al. 2016; Ünal et al. 2017; Bamberg and Möser 2007). These results are timely, and have implications for the future governance of private forestry, given the diverse demands on forest use and management (Lagergren and Jönsson 2017). The study may further spur an interest for a novel knowledge approach in the context of adaptive management where knowledge is considered a key asset (Fabricius and Cundill 2014).

The differential effects of knowledge on management behaviors shown in this study indicate that it is problematic to simply refer to knowledge as an important determinant (cf. Floress et al. 2019). Comparable to previous research in the environmental domain (e.g., Frick et al. 2004), the results generally supported the more remote role of declarative compared to procedural knowledge in relation to management behaviors, including management inactivity. Furthermore, procedural subjective knowledge was a significant predictor even in the final step of the analyses in all the models, whereas results for procedural objective knowledge were less consistent. Hence, in line with previous studies (Vicente-Molina et al. 2013; Eggers et al. 2014), the importance of subjective knowledge in relation to diverse management strategies was supported. However, this study could not confirm that subjective knowledge was more important for management inactivity. Overall, the results verified a positive association between knowledge and forest management behaviors, irrespective of type of knowledge, with one exception: whereas being more knowledgeable about climate adaptation was associated with more frequently implementing adaptation measures (e.g., increasing the share of mixed and broadleaved forest), it was also associated with management inactivity. A less proactive approach to the risk of future damages in forests has been found among less engaged owners (Gan et al. 2015). However, not implementing certain management measures may also reflect a willingness to rely on the forest's own ability to adapt through evolutionary processes (i.e., passive adaptation) (Keskitalo et al. 2016; Hagerman and Pilai 2018).

By confirming the different value basis of production and mitigation (substitution) management versus biodiversity management, and the dual value basis of climate adaptation, this study further expands on how the owners' emphasis on SE versus ST values are relevant for forest management behaviors (e.g., Dreschel et al. 2017; Eriksson 2018a, b). As expected, the importance of basic values generally decreased after the inclusion of more specific variables, 


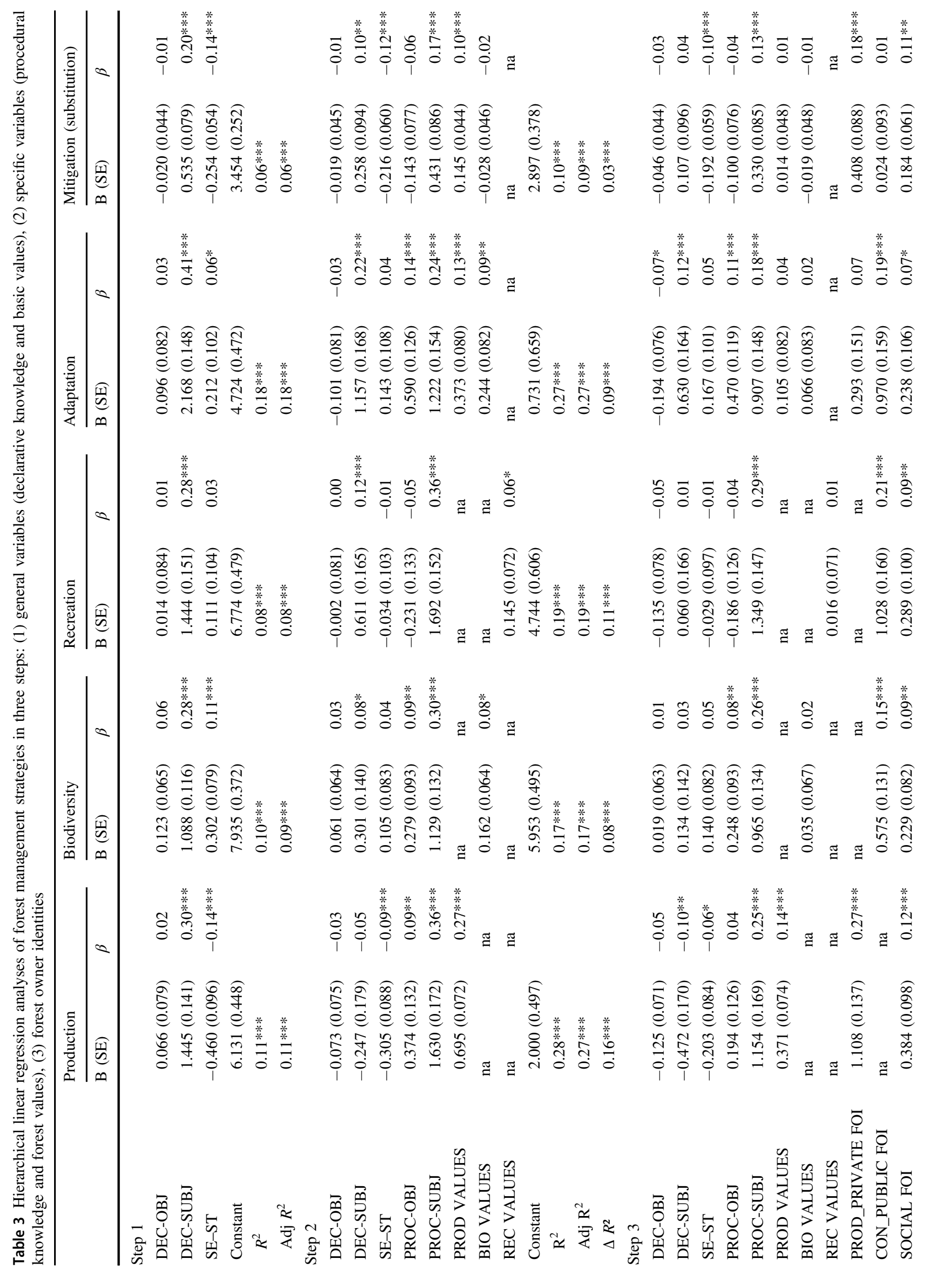




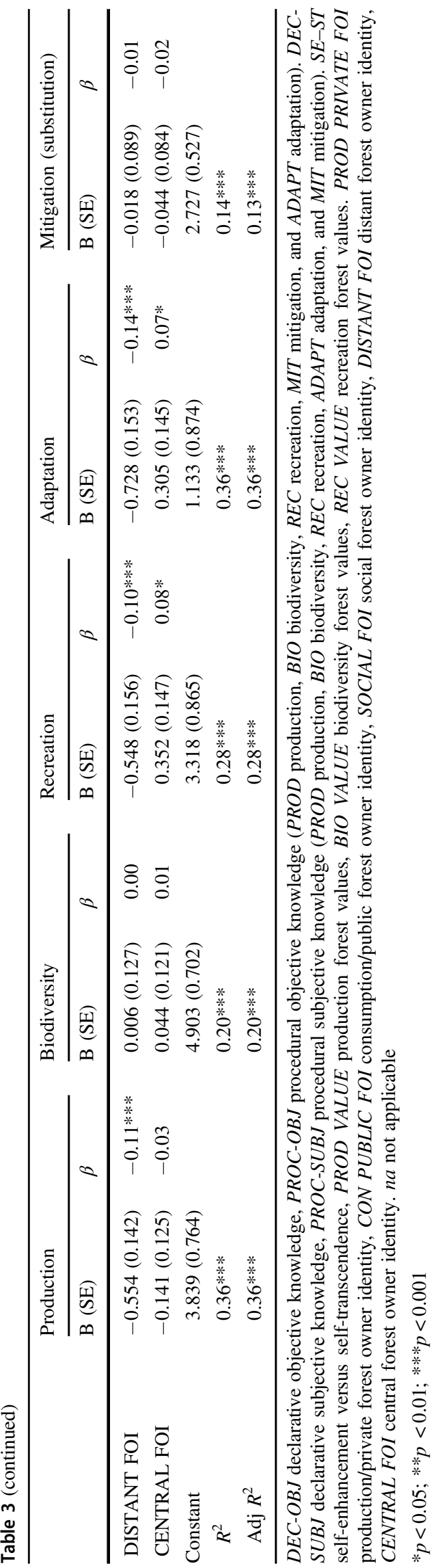

although not in relation to production and mitigation (substitution) management. Results suggest that value priorities (i.e., production values) are particularly important for production management. Since situational constraints may prevent values from having an impact on actual behavior (Steg et al. 2014; see also Põllumäe et al. 2014), the weaker effect of non-production values on management behaviors in this sample may stem from the production-oriented focus of forestry in Sweden (Keskitalo et al. 2016; Andersson and Keskitalo 2018). Even though there are no regulatory barriers to alternative management, the production forestry culture may, through normative processes, facilitate production and discourage alternatives. The study further revealed that the internalization of core interests (i.e., production versus consumption) in terms of forest owner identities was relevant for management behaviors. The results are generally in line with depictions of identity as a mediator between value priorities and behaviors (cf. Gatersleben et al. 2017). Previous studies have confirmed that social factors play an important role for forest owners' behaviors (Ruseva et al. 2014; Eriksson 2018a). This study advances this line of research by outlining a potential psychological mechanism for how the social context may influence behaviors. Owners interacting with other owners in various ways are likely to internalize perceptions of being a social owner, and this connectedness to others may in turn facilitate an active management approach. Since the Social FOI was positively associated with diverse management strategies, it is worth pointing out that the owners' networks seem to facilitate different management objectives, despite the emphasis on production in the Swedish forestry context.

Active or passive forest management approaches may be advocated depending on, for example, the purpose of the management, such as maximizing certain forest functions or multifunctionality (e.g., Hagerman and Pilai 2018; CruzAlonso et al. 2019; White and Long 2019; Williams and Powers 2019). Whereas this study showed that certain structural characteristics were associated with management inactivity (owning a smaller forest holding, being female, and owning forest in the north and middle regions in Sweden) (cf. Eriksson 2018b), results further revealed that an overall lesser focus on production (knowledge and value priorities) and a lower identification with other owners also characterized management inactivity. Potentially reflecting the production focus in this context but also that a norm of active management is remaining in Sweden despite the lower regulatory demands on management (Bush 2010). Nonresident owners, and owners living in an urban context, were not more likely to display inactivity, thus indicating that spatial distance to the forest do not necessarily mean a lower involvement in management (cf. Huff et al. 2017). However, worth noticing is the importance of different competences for an active forest management approach 
Table 4 Hierarchical binary logistic regression analysis of management inactivity in three steps: (1) general variables (declarative knowledge and basic values), (2) specific variables (procedural knowledge and forest values), (3) forest owner identities

\begin{tabular}{|c|c|c|c|c|c|c|c|c|c|}
\hline & \multicolumn{3}{|l|}{ Step 1} & \multicolumn{3}{|l|}{ Step 2} & \multicolumn{3}{|l|}{ Step 3} \\
\hline & B (SE) & Wald & $\operatorname{Exp}(\mathrm{B})$ & B (SE) & Wald & $\operatorname{Exp}(\mathrm{B})$ & B (SE) & Wald & $\operatorname{Exp}(\mathrm{B})$ \\
\hline DEC-OBJ & $-0.200(0.059)$ & $11.302 * * *$ & 0.819 & $-0.111(0.067)$ & 2.702 & 0.895 & $-0.073(0.073)$ & 0.995 & 0.930 \\
\hline DEC-SUBJ & $-0.861(0.109)$ & $62.195 * * *$ & 0.423 & $-0.195(0.168)$ & 1.356 & 0.822 & $-0.076(0.179)$ & 0.179 & 0.927 \\
\hline SE-ST & $0.077(0.072)$ & 1.156 & 1.080 & $0.011(0.086)$ & 0.016 & 1.011 & $-0.043(0.090)$ & 0.232 & 0.958 \\
\hline PROC-OBJ PROD & & & & $-0.433(0.125)$ & $11.898 * * *$ & 0.649 & $-0.332(0.134)$ & $6.088^{*}$ & 0.718 \\
\hline PROC-OBJ BIO & & & & $-0.371(0.104)$ & $12.652 * * *$ & 0.690 & $-0.353(0.109)$ & $10.447 * * *$ & 0.703 \\
\hline PROC-OBJ REC & & & & $-0.320(0.111)$ & $8.268 * *$ & 0.726 & $-0.344(0.117)$ & $8.678 * *$ & 0.709 \\
\hline PROC-OBJ ADAPT & & & & $0.440(0.116)$ & $14.350 * * *$ & 1.552 & $0.531(0.124)$ & $18.271 * * *$ & 1.701 \\
\hline PROC-OBJ MIT & & & & $0.051(0.121)$ & 0.176 & 1.052 & $-0.022(0.129)$ & 0.030 & 0.978 \\
\hline PROC-SUBJ PROD & & & & $-0.649(0.175)$ & $13.768 * * *$ & 0.523 & $-0.426(0.187)$ & $5.207 *$ & 0.653 \\
\hline PROC-SUBJ BIO & & & & $0.197(0.183)$ & 1.158 & 1.218 & $0.277(0.197)$ & 1.987 & 1.320 \\
\hline PROC-SUBJ REC & & & & $0.077(0.155)$ & 0.247 & 1.080 & $0.089(0.165)$ & 0.294 & 1.094 \\
\hline PROC-SUBJ ADAPT & & & & $-0.336(0.164)$ & $4.199 *$ & 0.715 & $-0.218(0.173)$ & 1.584 & 0.804 \\
\hline PROC-SUBJ MIT & & & & $0.082(0.176)$ & 0.216 & 1.085 & $0.075(0.188)$ & 0.160 & 1.078 \\
\hline PROD VALUES & & & & $-0.415(0.065)$ & $40.482 * * *$ & 0.660 & $-0.225(0.072)$ & $9.728 * *$ & 0.798 \\
\hline BIO VALUES & & & & $0.009(0.082)$ & 0.011 & 1.009 & $0.029(0.090)$ & 0.103 & 1.029 \\
\hline REC VALUES & & & & $0.004(0.075)$ & 0.003 & 1.004 & $-0.031(0.080)$ & 0.149 & 0.970 \\
\hline PROD_PRIVATE FOI & & & & & & & $-0.492(0.150)$ & $10.751 * * *$ & 0.612 \\
\hline CON_PUBLIC FOI & & & & & & & $0.057(0.146)$ & 0.154 & 1.059 \\
\hline SOCIAL FOI & & & & & & & $-0.613(0.113)$ & $29.252 * * *$ & 0.542 \\
\hline DISTANT FOI & & & & & & & $0.352(0.137)$ & $6.609 * *$ & 1.422 \\
\hline CENTRAL FOI & & & & & & & $-0.150(0.129)$ & 1.346 & 0.861 \\
\hline Constant & $1.908(0.339)$ & $31.635 * * *$ & 6.739 & $4.683(0.619)$ & $57.177 * * *$ & 108.04 & $4.289(0.852)$ & $25.331 * * *$ & 72.905 \\
\hline Nagelkerke $R$ square & 0.12 & & & 0.27 & & & 0.36 & & \\
\hline-2 Log likelihood & 1134.25 & & & 1010.69 & & & 921.11 & & \\
\hline
\end{tabular}

$D E C-O B J$ declarative objective knowledge, $P R O C-O B J$ procedural objective knowledge (PROD production, $B I O$ biodiversity, $R E C$ recreation, $M I T$ mitigation, and $A D A P T$ adaptation). DEC-SUBJ declarative subjective knowledge, $P R O C$-SUBJ procedural subjective knowledge (PROD production, $B I O$ biodiversity, $R E C$ recreation, $A D A P T$ adaptation, and $M I T$ mitigation). $S E-S T$ self-enhancement versus self-transcendence, $P R O D$ VALUE production forest values, BIO VALUE biodiversity forest values, REC VALUE recreation forest values. PROD PRIVATE FOI production/ private forest owner identity, CON PUBLIC FOI consumption/public forest owner identity, SOCIAL FOI social forest owner identity, DISTANT FOI distant forest owner identity, CENTRAL FOI central forest owner identity

${ }^{*} p<0.05, * * p<0.01, * * * p<0.001$

(i.e., more actual knowledge of biodiversity, recreation, and production management), showing that a broad range of skills is needed for owners to actively manage their forest.

When interpreting the results of this study, some limitations should be considered. Although a representative sample of forest owners in Sweden was surveyed and calibrated weights were used to avoid biases, active forest owners are likely overrepresented in the sample since they are likely more interested in the topic of the study. The measures were carefully developed and the internal reliability was generally good. However, despite being significant predictors, some of the scales measuring FOI displayed low reliability, indicating a need to develop these measures, and validate them in future research. The study was theoretically based, but since cross-sectional data cannot support causality, experimental evidence is needed to confirm the effect of independent variables on management behaviors (e.g., by exploring how different knowledge interventions influence management behaviors). While an overall assessment of the importance of psychological predictors for management behaviors is frequently missing in previous studies, the level of explained variance of production and climate adaptation management behaviors was comparable to results by Karppinen (2005) and Dreschel et al. (2017), and the level of explained variance in biodiversity and recreation management was equivalent to that in the study by Eriksson (2017). To develop the understanding of the individual drivers of forest management behaviors, it may be valuable to consider interactions between knowledge and value priorities in future research (e.g., values may 
be important for the acquisition of knowledge) (Thorn and Bogner 2018). In addition, to determine the generality of the results, there is a need to explore how different types of knowledge (including local and traditional knowledge) and value priorities, as well as different indicators of management behaviors, are related in diverse samples and contexts.

\section{Conclusion}

This study distinguished between actual knowledge, confidence, and value priorities, and confirms the independent effects of these factors along with forest owner identities on management behaviors among forest owners. Its results contribute novel insights for the understanding of the individual drivers of forest management behaviors, and the approach may be drawn upon to advance the understanding of the psychological basis of natural resource management more generally. In addition, the study has implications for governance. For example, more actual forest knowledge may not only lead to more informed management decisions; this study suggests that increasing particularly procedural knowledge of different management strategies may facilitate management. Although supporting social networks and increasing actual knowledge of different management strategies are likely to encourage a more active management approach, boosting the owner's confidence to implement specific management strategies (e.g., production or recreation) is important in order to facilitate particular management aims. Since a more varied forest may be more resistant to damage (e.g., Jactel et al. 2017), there may be a need to ensure that cultural and social factors do not prevent the diversity in owners' value profiles from being realized in their management practices. Moreover, by increasing the salience of specific owner identities in outreach to owners, specific forest functions may be encouraged.

\section{Data Availability}

The dataset analysed during the current study is available from the corresponding author upon reasonable request after the completion of the project.

Acknowledgements The authors would like to thank the participating forest owners for completing the survey and two anonymous reviewers for their constructive comments. Open access funding provided by Umea University.

Funding This study was financed by Brattåsstiftelsen (grant number: F17:03).

Author Contributions Study design, questionnaire, analysis, and paper preparation were performed by LE. CF has contributed to parts of the questionnaire (mainly objective knowledge questions and forest management behaviors).

\section{Compliance with Ethical Standards}

Conflict of Interest The authors declare that they have no conflict of interest.

Ethical Approval The study was conducted in accordance with the ethical standards of the institutional and/or national research committee and with the 1964 Helsinki declaration and its later amendments or comparable ethical standards.

Informed Consent Informed consent was obtained from all individual participants included in the study.

Publisher's note Springer Nature remains neutral with regard to jurisdictional claims in published maps and institutional affiliations.

Open Access This article is licensed under a Creative Commons Attribution 4.0 International License, which permits use, sharing, adaptation, distribution and reproduction in any medium or format, as long as you give appropriate credit to the original author(s) and the source, provide a link to the Creative Commons license, and indicate if changes were made. The images or other third party material in this article are included in the article's Creative Commons license, unless indicated otherwise in a credit line to the material. If material is not included in the article's Creative Commons license and your intended use is not permitted by statutory regulation or exceeds the permitted use, you will need to obtain permission directly from the copyright holder. To view a copy of this license, visit http://creativecommons. org/licenses/by/4.0/.

\section{References}

Aguilar FX, Cai Z, Butler B (2017) Proximal association of and management preferences: evidence from family forest owners. PLoS ONE 12(1):e0169667. https://doi.org/10.1371/journal. pone. 0169667

Ajzen I (2002) Perceived behavioral control, self-efficacy, locus of control, and the theory of planned behavior. J Appl Soc Psychol 32:665-683. https://doi.org/10.1111/j.1559-1816.2002.tb00236.x

Andersson E, Keskitalo C (2018) Adaptation to climate change? Why business-as-usual remains the logical choice in Swedish forestry. Glob Environ Change 48:76-85. https://doi.org/10.1016/j. gloenvcha.2017.11.004

Bamberg S, Möser G (2007) Twenty years after Hines, Hungerford, and Tomera: a new meta-analysis of psycho-social determinants of pro-environmental behaviour. J Environ Psychol 27:14-25. https://doi.org/10.1016/j.jenvp.2006.12.002

Bandura A (1977) Social learning theory. Prentice Hall, Englewood Cliffs, NJ

Bellassen V, Luyssaert S (2014) Carbon sequestration: managing forests in uncertain times. Nature 506:153-155. https://doi.org/ $10.1038 / 506153 a$

Bergstèn S, Stjernström O, Pettersson Ö (2018) Experiences and emotions among private forest owners versus public interests: Why ownership matters. Land Use Policy 79:801-811. https:// doi.org/10.1016/j.landusepol.2018.08.027

Bissonnette J-F, Dupras J, Doyon F, Chion C, Tardif J (2017) Perceptions of small private forest owner's vulnerability and adaptive capacity to environmental disturbances and climate change: views from a heterogeneous population in Southern Quebec, 
Canada. Small-Scale For 16:367-393. https://doi.org/10.1007/ s11842-016-9361-y

Blennow K, Persson J, Tomé M, Hanewinkel M (2012) Climate Change: believing and seeing implies adapting. PLoS ONE 7(11): e50182. https://doi.org/10.1371/journal.pone.0050182

Bliss JC, Martin AJ (1988) Identity and private forest management. Soc Nat Resour 1:365-376

Burke PJ, Stets JE (2009) Identity theory. Oxford University Press, New York, NY

Bush T (2010) Biodiversity and sectoral responsibility in the development of Swedish forestry policy, 1988-1993. Scand J Hist 35:471-498. https://doi.org/10.1080/03468755.2010.528249

Coté M-A, Gilbert D, Nadeau S (2016) Impact of changes in the sociological characteristics of small-scale forest owners on timber harvesting behavior in Quebec, Canada. Small-Scale For 15:375-392. https://doi.org/10.1007/s11842-016-9328-z

Cruz-Alonso V, Ruiz-Benito P, Villar-Salvador P, Rey-Benayas JM (2019) Long-term recovery of multifunctionality in Mediterranean forests depends on restoration strategy and forest type. J Appl Ecol 56:745-757. https://doi.org/10.1111/1365-2664.13340

De Groot JIM, Steg L (2008) Value orientations to explain beliefs related to environmental significant behavior. How to measure egoistic, altruistic, and biospheric value orientations. Environ Behav 40:330-354. https://doi.org/10.1177/0013916506297831

Díaz-Siefer P, Neaman A, Salgado E, Celis-Diez JL, Otto S (2015) Human-environment system knowledge: a correlate of proenvironmental behavior. Sustainability 7:15510-15526. https:// doi.org/10.3390/su71115510

Dietz T, Stern PC, Guagnano GA (1998) Social structural and social psychological bases of environmental concern. Environ Behav 30:450-471. https://doi.org/10.1177/001391659803000402

Drescher M, Warriner GK, Farmer JR, Larson BMH (2017) Private landowners and environmental conservation: a case study of socialpsychological determinants of conservation program participation in Ontario. Ecol Soc 22(1):44. https://doi.org/10.5751/ ES-09118-220144

Eggers J, Lämås T, Lind T, Öhman K (2014) Factors influencing the choice of management strategy among small-scale private forest owners in Sweden. Forests 5:1695-1716. https://www.mdpi.com/ $1999-4907 / 5 / 7 / 1695 / \mathrm{pdf}$

Eriksson L (2017) The importance of threat, strategy, and resource appraisals for long-term proactive risk management among forest owners in Sweden. J Risk Res 20:868-886. https://doi.org/10. 1080/13669877.2015.1121905

Eriksson L (2018a) Effects of policy measures and moderating factors on climate change adaptation among private forest owners in Sweden. Soc Nat Resour 31:409-423. https://doi.org/10.1080/ 08941920.2017.1382629

Eriksson L (2018b) Explaining gender differences in private forest risk management. Scand J For Res 33:716-723. https://doi.org/10. 1080/02827581.2018.1453944

Eriksson L, Nordlund A, Westin K (2013) The general public's support for forest policy in Sweden: a value belief approach. J Environ Plan Manag 56:850-867. https://doi.org/10.1080/ 09640568.2012.708324

Eurostat (2017) Agriculture, forestry, and fishery statistics. Statistical books Eurostat, Luxembourg. https://doi.org/10.2785/570022

Fabricius C, Cundill G (2014) Learning in adaptive management: insights from published practice. Ecol Soc 19(1):29. https://doi. org/10.5751/ES-06263-190129

Ferraro R, Edson Escalas J, Bettman JR (2011) Our possessions, our selves: Domains of self-worth and the possession-self link. J Consum Psychol 21:169-177. https://doi.org/10.1016/j.jcps.2010.08.007

Ficko A, Lidestav G, Ní Dhubháin A, Karppinen H, Zivojinovic I, Westin K (2017) European private forest owner typologies: a review of methods and use. For Policy Econ 99:21-31. https:// doi.org/10.1016/j.forpol.2017.09.010

Fischer AP (2019) Adapting and coping with climate change in temperate forests. Glob Environ Change 54:160-171. https://doi.org/ 10.1016/j.gloenvcha.2018.10.011

Fischer AP, Charnley S (2012) Private forest owners and invasive plants: risk perception and management. Invasive Plant Sci Manag 5:375-389. https://doi.org/10.1614/IPSM-D-12-00005.1

Floress K, Huff ES, Snyder SA, Koshollek A, Butler S, Allred SB (2019) Factors associated with family forest owner actions: a vote-count metaanalysis. Landsc Urban Plan 188:19-29. https:// doi.org/10.1016/j.landurbplan.2018.08.024

Feliciano D, Bouriaud L, Brahic E, Deuffic P, Dobsinska Z, Jarsky V, Lawrence A, Nybakk E, Quiroga S, Suarez C, Ficko A (2017) Understanding private forest owners' conceptualisation of forest management: evidence from a survey in seven European countries. J Rural Stud 54:162-176. https://doi.org/10.1016/j.jrurstud. 2017.06.016

Frick J, Kaiser FG, Wilson M (2004) Environmental knowledge and conservation behavior: exploring prevalence and structure in a representative sample. Personal Individ Differ 37:1597-1613. https://doi.org/10.1016/j.paid.2004.02.015

Fulton DC, Manfredo MJ, Lipscomb J (1996) Wildlife value orientations: a conceptual and measurement approach. Hum Dimens Wildl $1: 24-47$

Gan J, Jarrett A, Johnson Gaither C (2015) Landowner response to wildfire risk: Adaptation, mitigation or doing nothing. J Environ Manag 159:186-191. https://doi.org/10.1016/j.jenvman.2015.06. 014

Gatersleben B, Murtagh N, Cherry M, Watkins M (2017) Moral, wasteful, frugal, or thrifty? Identifying consumer identities to understand and manage pro-environmental behavior. Environ Behav 51:24-49. https://doi.org/10.1177/0013916517733782

Geiger SM, Geiger M, Wilhelm O (2019a) Environment-specific vs. general knowledge and their role in pro-environmental behavior. Front Psychol 10:718. https://doi.org/10.3389/fpsyg.2019.00718/ full

Geiger JL, Steg L, van der Werff E, Ünal AB (2019b) A meta-analysis of factors related to recycling. J Environ Psychol 64:78-97. https://doi.org/10.1016/j.jenvp.2019.05.004

Germain RH, Ellis B, Stehman SV (2014) Does landowner awareness and knowledge lead to sustainable forest management? A Vermont case study. J Ext 52:6RIB3

Hagerman SM, Pilai R (2018) Responding to climate change in forest management: two decades of recommendations. Front Ecol Environ 16:579-587. https://doi.org/10.1002/fee.1974

Hendee JT, Flint CG (2013) Managing private forestlands along the public-private interface of Southern Illinois: Landowner forestry decisions in a multi-jurisdictional landscape. For Policy Econ 34:47-55. https://doi.org/10.1016/j.forpol.2013.04.009

Hogl K, Pregernig M, Weiss G (2005) What is new about new forest owners? A typology of private forest ownership in Austria. Small-Scale Econ Manag Policy 4:325-342. https://doi.org/10. 1007/s11842-005-0020-y

Huff ES, Leahy JE, Kittredge DB, Noblet CL, Weiskittel AR (2017) Psychological distance of timber harvesting for private woodland owners. For Policy Econ 81:48-56. https://doi.org/10.1016/j.forpol. 2017.04.007

Hurlbert M et al. (2019) Risk management and decision making in relation to sustainable development. In Shukla PR, et al. (eds) Climate change and land: an IPCC special report on climate change, desertification, land degradation, sustainable land management, food security, and greenhouse gas fluxes in terrestrial ecosystems. In press. https://www.ipcc.ch/site/assets/uploads/ sites/4/2019/11/10_Chapter-7.pdf 
IBM Corp (2016) IBM SPSS Statistics for Windows, Version 24.0. Armonk, NY: IBM Corp

Ingemarson F, Lindhagen A, Eriksson L (2006) A typology of smallscale private forest owners in Sweden. Scand J Res 21:249-259. https://doi.org/10.1080/02827580600662256

IPBES (2013) Decision IPBES-2/4: conceptual framework for the intergovernmental science-policy platform on biodiversity and ecosystem services. https://ipbes.net/sites/default/files/downloa ds/Decision\%20IPBES_2_4.pdf

Jactel H, Bauhus J, Boberg J, Bonal D, Castagneyrol B, Gardiner B, Gonzalez-Olabarria JR, Koricheva J, Meurisse N, Brockerhoff EG (2017) Tree diversity drives forest stand resistance to natural disturbances. Curr Rep 3(3):223-243. https://doi.org/10.1007/ s40725-017-0064-1

Johansson J, Keskitalo ECH (2014) Coordinating and implementing multiple systems for forest management: implications of the regulatory framework for sustainable forestry in Sweden. J Nat Resour Policy Res 6:117-133. https://doi.org/10.1080/19390459.2014. 913363

Joshi S, Arano KG (2009) Determinants of private forest management decisions: A study on West Virginia NIPF landowners. For Policy Econ 11:118-125. https://doi.org/10.1016/j.forpol.2008. 10.005

Kaiser FG, Fuhrer U (2003) Ecological behavior's dependency on different forms of knowledge. Appl Psychol Int Rev 52:598-613. https://doi.org/10.1111/1464-0597.00153

Karppinen H (2005) Forest owners' choice of reforestation method: an application of the theory of planned behaviour. For Policy Econ 7:393-409. https://doi.org/10.1016/j.forpol.2003.06.001

Kelly EC, Gold GJ, Tommaso JD (2017) The willingness of nonindustrial private forest owners to enter California's carbon offset market. Environ Manag 60:882-895. https://doi.org/10.1007/ s00267-017-0918-0

Keskitalo ECH, Bergh J, Felton A, Björkman C, Berlin M, Axelsson P, Ring E, Ågren A, Roberge J-M, Klapwijk MJ, Boberg J (2016) Adaptation to climate change in Swedish forestry. Forests 7:28. https://doi.org/10.3390/f7020028

Kreye MM, Adams DC, Ober HK (2018) Protecting imperiled wildlife species on private lands: forest owner values and response to government interventions. Ecol Econ 149:254-264. https://doi. org/10.1016/j.ecolecon.2018.03.016

Lagergren F, Jönsson AM (2017) Ecosystem model analysis of multiuse forestry in a changing climate. Ecosyst Serv 26:209-224. https://doi.org/10.1016/j.ecoser.2017.06.007

Lähdesmäki M, Matilainen A (2014) Born to be a forest owner? An empirical study of the aspects of psychological ownership in the context of inherited forests in Finland. Scand J Res 29:101-110. https://doi.org/10.1080/02827581.2013.869348

Lawrence A, Dandy N (2014) Private landowners' approaches to planting and managing forests in the UK: what's the evidence? Land Use Policy 36:351-360. https://doi.org/10.1016/j.la ndusepol.2013.09.002

Lidestav G, Berg Lejon S (2013) Harvesting and silvicultural activities in Swedish family forestry-behavior changes from a gender perspective. Scand J Res 28:136-142. https://doi.org/10.1080/ 02827581.2012 .701324

Lindner M, Fitzgerald JB, Zimmermann NE, Reyer C, Delzon S, van der Maaten E, Schelhaas M-J, Lasch P, Eggers J, van der Maaten-Theunissen M, Suckow F, Psomas A, Poulter B, Hanewinkel M (2014) Climate change and European forests: what do we know, what are the uncertainties, and what are the implications for forest management? J Environ Manag 146:69-83. https://doi.org/10.1016/j.jenvman.2014. 07.030

Marzano M, Fuller L, Quine CP (2017) Barriers to management of tree diseases: framing perspectives of pinewood managers around
Dothistroma Needle Blight. J Environ Manag 188:238-245. https://doi.org/10.1016/j.jenvman.2016.12.002

McFarlane BL, Boxall PC (2003) The role of social psychological and social structural variables in environmental activism: an example of the forest sector. J Environ Psychol 23:79-87. https://doi.org/ 10.1016/S0272-4944(02)00080-4

McFarlane BL, Watson DOT (2008) Perceptions of ecological risk associated with Mountain Pine Beetle (Dendroctonus ponderosae) infestations in Banff and Kootenay National Parks of Canada. Risk Anal 28:203-121. https://doi.org/10.1111/j.15396924.2008.01013.x

Ní Dhubháin AN, Cobanova R, Karppinen H, Mizaraite D, Ritter E, Slee B, Wall S (2007) The values and objectives of private forest owners and their influence on forestry behavior: the implication for entrepreneurship. Small-Scale For 6:347-357. https://doi.org/ 10.1007/s11842-007-9030-2

Nichiforel L, Keary K, Deuffic P et al. (2018) How private are Europe's private forests? A comparative property rights analysis. Land Use Policy 76:535-552. https://doi.org/10.1016/j.la ndusepol.2018.02.034

Nguyen TPL, Seddaiu G, Roggero PP (2019) Declarative or procedural knowledge? Knowledge for enhancing farmers' mitigation and adaptation behaviour to climate change. J Rural Stud 67:46-56. https://doi.org/10.1016/j.jrurstud.2019.02.005

Põllumäe P, Korjus H, Paluots T (2014) Management motives of Estonian private forest owners. For Policy Econ 42:8-14. https:// doi.org/10.1016/j.forpol.2014.02.007

Roczen N, Kaiser FG, Bogner FX, Wilson M (2014) A competence model for environmental education. Environ Behav 46:972-992. https://doi.org/10.1177/0013916513492416

Rohan MJ (2000) A rose by any name? The values construct. Pers Soc Psychol Rev 4:255-277. https://doi.org/10.1207/ S15327957PSPR0403_4

Ruseva TB, Evans TP, Fischer BC (2014) Variations in the social networks of forest owners: The effect of management activity, resource professionals, and ownership size. Small-Scale For 13:377-395. https://doi.org/10.1007/s11842-014-9260-z

Sagor ES, Becker DR (2014) Personal networks and private forestry in Minnesota. J Environ Manag 132:145-154. https://doi.org/10. 1016/j.jenvman.2013.11.001

Schwartz SH (1992) Universals in the content and structure of values: theoretical advances and empirical tests in 20 countries. Adv Exp Soc Psychol 25:1-65. https://doi.org/10.1016/S0065-2601(08) 60281-6

Schwartz SH (1994) Are there universal aspects in the structure and contents of human values? J Soc Issues 50:19-45. https://doi.org/ 10.1111/j.1540-4560.1994.tb01196.x

Shi J, Visschers VHM, Siegrist M, Arvai J (2016) Knowledge as a driver of public perceptions about climate change reassessed. Nat Clim Change 6:759-762. https://doi.org/10.1038/nclimate2997

Silver EJ, Leahy JE, Weiskittel AR, Noblet CL, Kittredge DB (2015) An evidence-based review of timber harvesting behavior among private woodland owners. J Forestry 113:490-499. https://doi. org/10.5849/jof.14-089

Sousa-Silva R, Verbist B, Lomba Â, Valent P, Suškevičs M, Picard O, Hoogstra-Klein MA, Cosofret C-V, Bouriaud L, Ponette Q, Verheyen K, Muys B (2018) Adapting forest management to climate change in Europe: linking perceptions to adaptive responses. For Policy Econ 90:22-30. https://doi.org/10.1016/j. forpol.2018.01.004

Steele J, Chandran RS, Grafton WN, Huebner CD, McGill DW (2006) Awareness and management of invasive plants among West Virginia Woodland owners. J For 104:248-253. https://doi.org/ 10.1093/jof/104.5.248

Steg L, Bolderdijk JW, Keizer K, Perlaviciute G (2014) An integrated framework for encouraging pro-environmental behaviour: The 
role of values, situational factors and goals. J Environ Psychol 38:104-115. https://doi.org/10.1016/j.jenvp.2014.01.002

Stern PC (2000) Toward a coherent theory of environmentally significant behavior. J Soc Issues 56:407-424. https://doi.org/10. 1111/0022-4537.00175

Swedish Forest Agency (SFA) (2014) Skogsstatistisk årsbok 2014 [Swedish Statistical Yearbook of Forestry]. The Swedish Forest Agency, Jönköping

Swedish Gov Bill (2007) En skogspolitik i takt med tiden [A Forest Policy in Line with the Times]. Ministry of Agriculture, Stockholm. https://www.regeringen.se/49bba7/contentassets/80c43f4e251b4 3939c8bf4d3a54ebd01/en-skogspolitik-i-takt-med-tiden-prop.200708108

Swedish University of Agricultural Science (SLU) (2018) Forest statistics 2018. SLU, Uppsala. https://www.slu.se/globalassets/ew/ org/centrb/rt/dokument/skogsdata/skogsdata_2018_webb.pdf

Thompson DW, Hansen EN (2013) Carbon storage on non-industrial private forestland: an application of the theory of planned behavior. SmallScale For 12:631-657. https://doi.org/10.1007/s11842-013-9235-5

Thompson JR, Canham CD, Morreale L, Kittredge DB, Butler B (2017) Social and biophysical variation in regional timber harvest regimes. Ecol Appl 27:942-955. https://doi.org/10.1002/eap.1497

Thorn C, Bogner FX (2018) How environmental values predict acquisition of different cognitive knowledge types with regard to forest conservation. Sustainability 10:2188. https://doi.org/10. 3390/su10072188

Thorn S, Leverkus AB, Thorn CJ, Beudert B (2019) Education and knowledge determine preference for bark beetle control measures in El Salvador. J Environ Manag 232:138-144. https://doi.org/10. 1016/j.jenvman.2018.11.032

Trivino M, Pohjanmies T, Mazziotta A, Juutinen A, Podkopaev D, Le Tortorec E, Mönkkönen M (2017) Optimizing management to enhance multifunctionality in a boreal forest landscape.
J Appl Ecol 54:61-70. https://doi.org/10.1111/1365-2664. 12790

Ünal AB, Steg L, Gorsira M (2017) Values versus environmental knowledge as triggers of a process of activation of personal norms for eco-driving. Environ Behav 50:1092-1118. https://doi. org/10.1177/0013916517728991

United Nations (2015) Transforming our world: the 2030 agenda for sustainable development. A/RES/70/1. United Nations, New York, NY

Vicente-Molina AA, Fernández-Sáinz A, Izagirre-Olaizola J (2013) Environmental knowledge and other variables affecting proenvironmental behaviour: comparison of university students from emerging and advanced countries. J Clean Prod 61:130-138. https://doi.org/10.1016/j.jclepro.2013.05.015

Vulturius G, André K, Geiger Swartling Å, Brown C, Rounsevell MDA, Blanco V (2018) The relative importance of subjective and structural factors for individual adaptation to climate change by forest owners in Sweden. Reg Environ Change 18:511. https:// doi.org/10.1007/s10113-017-1218-1

Walton TN, Emmet Jones R (2018) Ecological identity: the development and assessment of a measurement scale. Environ Behav 50:657-689. https://doi.org/10.1177/0013916517710310

Weiss G, Lawrence A, Lidestav G, Feliciano D, Hujala T, Sarvašová Z, Dobšinská Z, Živojinović I (2019) Research trends: Forest ownership in multiple perspectives. For Policy Econ 99:1-8. https://doi.org/10.1016/j.forpol.2018.10.006

White AM, Long JW (2019) Understanding ecological contexts for active reforestation following wildfires. New Forest 50:41-56. https://doi.org/10.1007/s11056-018-9675-z

Williams NG, Powers MD (2019) Carbon storage implications of active management in mature Pseudotsuga menziesii forests of western Oregon. For Ecol Manage 432:761-775. https://doi.org/ 10.1016/j.foreco.2018.10.002 